\title{
ПОЛИТИЧЕСКАЯ ТЕОРИЯ*
}

\section{Т. Иногути}

Ключевые слова: нормативная политическая теория, эмпирическая политическая теория, политология, институционализм, глобализм.

Теория - это совокупность последовательных утверждений, основанная на наборе аксиом и предположений, имеющая логичную структуру, убедительная в нормативном аспекте и верифицируемая в отношении реальности. Политическая теория - это набор утверждений о том, "кто получает что, когда и как” (Гарольд Лассуэлл) и о “властном распределении ценностей в обществе” (Дэвид Истон), охватывающих весьма широкий спектр объектов.

В начале данной статьи исследуются происхождение и типы политической теории, среди которых выделяются классическая философия, эмпирическая политическая теория, формальная политическая теория. Далее рассматриваются четыре школы нормативной политической теории (конфликт, общие ценности, обмен и координирование) и шесть школ эмпирической политической теории (системная теория, бихевиоризм, теория рационального выбора, институционализм, нейроанализ и глобализм). Затем анализируется потребность упрочения диалога между нормативной и эмпирической политической теорией, или между “должно быть” и “является”. Так, нормативная политическая теория должна обращать более пристальное внимание на реализуемость и самодостаточность выдвигаемых предписаний, а эмпирическая политическая теория - подвергать более серьезному анализу нормативные высказывания. Для наглядного описания процесса диалога и точек пересечения внутри политической теории приводятся примеры.

\section{ПРОИСХОЖДЕНИЕ И ТИПЫ ПОЛИТИЧЕСКОЙ ТЕОРИИ}

Хотя политическая теория как часть современной дисциплины политологии возникла только в XX в., ее истоки, несомненно, лежат в идеях мыслителей древних Греции, Месопотамии, Египта, Индии и Китая. Можно привести отрывки из Аристотеля, Каутильи или Конфуция, чтобы продемонстрировать, что они являлись учеными-политологами и что эта наука, хотя и возникла недавно, обладает очень древними корнями. Одно из ключевых утверждений, на основании которого можно провести разграничение между политологией и другими общественными науками, заключается в том, что ее ранние версии (такие, как у упомянутых выше философов) во многом актуальны и для сегодняшней политической действительности. Аристотель часто упоминается в современных работах по политике и политологии; на Каутилью ссылаются в дискуссиях об искусстве управления государством; к Конфуцию обращаются при изучении авторитарной политики. Хотя об

ИНОГУТИ Такаси (猪口孝), президент Университета префектуры Ниигата, почетный профессор Токийского университета, бывший заместитель Генерального секретаря ООН. Для связи с авТором: unptokyo@unii.ac.jp

* Inoguchi Takashi. "Political theory." - International Encyclopedia of Political Science. L.: Sage, 2011, vol. 6, pp. 2050-2063. Публикуется с любезного разрешения автора и издательства. 
Аристотеле редко вспоминают, дискутируя на экономические темы, его идеи в этой области играют значительную роль в истории экономики. Все эти дисциплины сравнительно молоды, поскольку они приобрели статус наук уже на Западе в XX в., однако даже в начале XXI в. в политологии сохранилось многое от ее первоначальных версий. Таким образом, развитие этой науки представляет собой весьма сложный процесс.

В Западной Европе разграничение между сакральным и секулярным проводилось постепенно, но достаточно последовательно во времена Просвещения и Реформации и распространилось в дальнейшем по всему миру - по крайней мере, на поверхностном уровне. Следовательно, секуляризм тесно связан с западной культурой. Считается, что религия и политика были разделены на Западе с начала современной эпохи. То же самое можно сказать и об отношениях между религией и наукой. Вильям Оккамский дал раннее эпистемологическое обоснование того, что сейчас бы назвали "современной наукой”, проведя четкую разграничительную линию между реализмом и номинализмом. Реализм относится к школе мысли, согласно которой Бог существует в реальности, которая воспринимается как базис этого знания. Номинализм разделяет точку зрения, что Бог существует постольку, поскольку концепция Бога существует в человеческом воображении. На основе этого положения наука отделилась от сферы сакрального и достигла впечатляющего прогресса.

Понятно, что разделения “Бог” - “наука" и "Бог” - “политика" не произошло раз и навсегда; разница между наукой и политикой была незначи-

124 тельной. Во всяком случае, отделение политики от Бога было шагом вперед в проведении различий между политической теорией и философией, попыткой отделить Суд Божий от суждений ученых и политических лидеров.

Главной проблемой политологии является смесь нормативного и эмпирического. Норматив - суждение, на основании которого выносится вердикт о справедливости. В Средние века таковые исходили от католической церкви (хотя иногда вопрос решался и на дуэли). Сегодня секулярные дела рассматриваются судами, которые в некотором роде играют роль Бога. Концепция эмпирического относится к чему-либо, что может быть испытано опытным путем, проверено в обычной жизни. Вплоть до настоящего времени, когда нарастающее разграничение между сакральным и секулярным становится все более отчетливым (что позволило осуществлять “замеры действительности”), эмпирическая проверка не являлась расхожей практикой.

Политическая теория объединяет “под одним зонтиком” как классическую философию и эмпирическую политическую теорию, так и “формальную политическую теорию”. Классическая философия оперирует донаучным и доэмпирическим утверждениями о том, что такое справедливость, каким образом она должна достигаться и как должна формулироваться ее концепция. Эмпирическая политическая теория имеет дело с утверждениями, сделанными с научной и эмпирической точек зрения относительно того, как политика осуществляется в реальности. Формальная политическая теория имеет дело с логически и/или математически получаемыми утверждениями, которые могут или не могут получить подтверждение путем эмпирического тестирования. Иметь дело с нормативным и эмпирическим в принципе непросто. Смешение 
проблематик стало одной из тенденций последнего времени, возникшей как ответ на сверхузкую специализированность и изоляцию среди политологов, работающих с нормативным и эмпирическим соответственно. Взаимная изолированность этих двух типов теории порой заходит слишком далеко, так как грань между ними не всегда четко ясна.

На практике нормативная и эмпирическая политические теории крайне далеки друг от друга по нескольким причинам. Во-первых, различается природа знания, лежащего в их основе. Ученые, занимающиеся классической политической теорией, интересуются преимущественно философией, теологией и историей мысли, тогда как ученые-эмпирики большей частью связаны с экономикой, социологией, социальной психологией и другими прикладными науками (такими как неврология в политике). Во-вторых, сильно разнятся методы. Если классическая политическая теория - это в основном изучение и критика текстов, выстраивание системы аргументации, то эмпирическая политическая теория выполняет проверку гипотез на базе позитивистских практик и “замеров действительности”. Правда, эти различия недостаточно велики, чтобы усомниться в принадлежности двух типов теории к единой дисциплине - политологии, последователям которой притягательность тематики власти придает чувство идентичности и солидарности.

Типы политической теории - классическая философия, эмпирическая политическая теория и формальная политическая теория - подробно обсуждаются ниже.

\section{КЛАССИЧЕСКАЯ ФИЛОСОФИЯ}

Классическая философия охватывает практически все - от нормативного до эмпирического, предписаний и смеси всего вышеперечисленного. В “Великом учении” (“Да сюэ”) один из знаменитых конфуцианцев наставлял своих учеников, чтобы они поступали следующим образом: “Классифицировать вещи и явления, искать истину, совершенствовать самого себя (морально), устанавливать порядок и единодушие в семье, устанавливать порядок в государстве, умиротворять Поднебесную, не возвышаться над остальными". Дисциплина и постижение нового помогут обеспечить благополучие в семьях, и этот процесс станет основой государственного управления. Только пройдя через все эти стадии, ученики смогут достичь “мира во всем мире”.

Это философское утверждение можно описать несколькими способами: (a) основанная на авторитете концепция управления мудрейшими; (б) моралистическая концепция управления; и (в) концепция “государства-семьи”. Оно реализуется “от низов к верхам”, но насыщено авторитарными, патерналистскими и персоналистическими оттенками.

Не менее знаменитая классическая философия Никколо Макиавелли, автора "Государя", также содержит как нормативные, так и эмпирические данные. Он предупреждает своих читателей о том, что политика определяется добродетелью и богатством. Под добродетелью он подразумевает набор сильных черт, необходимых для борьбы с влиянием богатства, в числе которых есть и моральная сила. Задача этой философии, состоящей большей частью из предписаний, - научить монарха править разумно. В то же 
• время, зачастую Макиавелли как республиканца обвиняют в том, что его наставления были направлены на уничтожение монархии через пестование превосходства, недоверия и действия с позиции силы, что негативно сказывается на уровне народной поддержки, которая становилась все более решающим фактором.

Еще одной вехой классической философии выступают “Записки федералиста”, в которых часто видят предтечу эмпирической политической теории. Точка зрения, что федерализм - это жизнеспособная альтернатива унитарному государству, является тому примером. Данное утверждение перекликается с работами Уильяма Рикера (1964) и формальной политической теорией его Рочестерской школы, имеющей общее как с классической философией, так и с эмпирической политической теорией.

Знаменитый трактат Иммануила Канта “К вечному миру” подвергся эмпирической проверке в более позднее время, и эти попытки вызвали немало споров. В 1795 г. Кант выдвинул предположение, что для достижения вечного мира должны быть соблюдены три условия. Необходимо, во-первых, способствовать торговле, свободе перемещения и товарных сделок между нациями; во-вторых, поощрять республиканские формы политики, а не монархические, чтобы затруднить развязывание войны; в-третьих, создать международные институты для выражения различных мнений, содействия дискуссиям и урегулирования конфликтов. Формулировка Канта была переосмыслена в традициях эмпирической политической теории Майклом Дойлом, Брюсом Рассеттом и другими и облечена в концепциях либерального мира, демократического мира и “мира посредством консорииума”, из которых вторая пользуется наибольшей популярностью (Билл Клинтон и Джордж Буш-мл. применяли ее для оправдания американских военных интервенций). Сходство идей Канта с эмпирической политической теорией слишком очевидно, даже если это признают не всегда.

Томас Гоббс, возможно, наиболее часто упоминаемый в связи с темой государства в общественных науках автор (наряду с Максом Вебером и Карлом Марксом). Столкнувшись с проявлениями анархии как в Англии XVI в., так и за ее пределами, Гоббс предположил, что ответом на нее должны быть абсолютизм и абсолютистское государство. Вот почему Гоббс - один из тех философов, на которых чаще всего ссылаются при обсуждении недееспособных государств и “стран-изгоев". Описывая и анализируя примеры анархии (Камбоджа в 1980-х и 1990-х годах, Сомали с начала 1990-х годов, Судан в 1990-х и 2000-х годах, Афганистан в последние 40 лет, Демократическая республика Конго в течение большей части 1990-х и 2000-х годов, Руанда в 1990-х и 2000-х годах, а также Западные Балканы в 1990-х и 2000-х годах), многие авторы указывают на необходимость установить монополию на применение силы и легитимизировать использование силового метода в начальной, критической фазе государственного строительства, а также искать консенсус с международным сообществом. Сходные выводы и рекомендации предлагаются для иллюстрации процесса государственного строительства под влиянием демократических настроений и глобалистских тенденций, а также процесса становления абсолютизма, возникающего из претензий на государственный суверенитет. Одна из его форм может быть выражена концепцией “суверен- 
ной демократии", автором которой является близкий к президенту России Владислав Сурков. Концепция подразумевает, что государство обладает суверенитетом, его представители на высшем уровне избираются демократическим путем, однако исключено любое иностранное вмешательство, в том числе демократическими способами (таким как попытки “цветных революций” в Украине, Грузии и Киргизии). Китайские лидеры также рассматривают “мирные изменения" как проклятие, означающее интервенцию с целью насильственно изменить режим под лозунгами "за права человека и демократию”, поэтому в годовщину событий на площади Тяньаньмэнь (4 июня 1989 г.) Китай объявил о введении режима чрезвычайного положения.

\section{ЭМПИРИЧЕСКАЯ ПОЛИТИЧЕСКАЯ ТЕОРИЯ}

Эмпирическая политическая теория ставит своей задачей создание гипотез, которые могут быть эмпирически протестированы, а также полезны для обобщений. Другими словами, она придает наибольшее значение двум аспектам исследований: (1) эмпирической валидации (или фальсификации) и (2) эмпирическому обобщению (или теоретизированию): сперва предлагается эмпирически верифицируемая гипотеза, затем она тестируется. Если гипотеза подтверждается, на ее основе можно проводить обобщения. Хорошим примером является модель Дугласа Хиббса (1989) о голосовании на выборах президента США. Как отмечал ученый, вопрос о том, будет ли кандидат от правящей партии избран президентом, определяется сочетанием двух факторов: количеством потерь в войсках США на поле боя и динамикой чистого дохода на душу населения за последние годы. В основе этой модели лежит гипотеза о том, что избиратели желают мира (отсутствия потерь) и благополучия (роста дохода). Так, в предвыборной гонке 2008 г. ключевую роль играли операция “Большая волна” в Ираке и субстандартные кредиты на жилье. С одной стороны, с 2007 г. потери в Ираке сокращались; с другой, из-за спада экономики снизились оптовые цены и устойчивость доллара. Реакция избирателей во многом зависела о того, сможет ли правительство предотвратить рецессию, простимулировав экономику путем “закачивания" в нее большого количества денег. В итоге Джон Маккейн, высказавшийся против этой меры, потерпел поражение.

В ряде исследований высказывается предположение о наличии взаимосвязи между доверием и здоровьем: граждане, недовольные качеством социальных институтов, скорее всего будут жаловаться на плохое здоровье, как и те, кто не доверяет окружающим. Отмечается, что люди с меньшим вертикальным доверием не расположены доверять социальным институтам и, соответственно, не получают от них пользу, что приводит к утрате здоровья. Сходным образом, граждане с низким горизонтальным доверием не склонны доверять другим людям и работа в коллективе негативно сказывается на их самочувствии. Утрата здоровья измеряется по самостоятельным оценкам его состояния посредством опросного листа Всемирной организации здравоохранения. Это предложение интересно с точки зрения публичной политики, так как поддержание уверенности общества в социальных институтах важно само по себе. В противном случае, услуги, обеспечивающиеся этими институтами, не достигают населения в полном объеме. Таким образом, с кон- 
сервативной точки зрения осуществление публичной политики - это зависимая переменная, на которую влияет множество факторов и нечто, ощутимое физически (например, здоровье) или эмоционально (счастье или почет).

Электоральная система может как объединять граждан, так и сеять между ними разногласия. Ключевой аспект теории представительной демократии выбор электората. Представительная демократия требует выполнения двух условий: (1) честного представительства, отражающего предпочтения избирателей, и (2) государственной стабильности, позволяющей правительству выполнять политические обещания в отношении избирателей. Существуют две главные системы: пропорциональное представительство, при котором парламентские кресла распределяются в соответствии с процентом голосов, собранных партией, и мажсоритарное, в котором выигрывает кандидат, получивший наибольшее количество голосов в округе; этот метод дает непропорционально большое количество мест партиям, которые набирают большее количество голосов, и сокращает количество постов для партий с меньшим количеством голосов. Считается, что пропорциональная система дает честное представительство, но не стабильность режима, в то время как мажоритарная система обеспечивает умеренно несправедливое представительство и стабильность. Последняя широко распространена во многих англоязычных странах, таких как США, Великобритания, Австралия, Канада и, до недавних пор, Новая Зеландия. Первая активно используется в континентальных европейских странах. В последнее время смешанная система, сочетающая в себе оба метода, стала более популярной, особенно в Азиатско-Тихоокеанском регионе, и, судя

128 по всему, она обеспечивает честное представительство и стабильность режима на достаточно удовлетворительном уровне.

Пропорциональное представительство может приводить к существенным противоречиям, как в Израиле или Ираке. Об израильском государстве иногда говорят, что оно совершило две институциональные ошибки в дни своего основания: во-первых, оказалось неспособным принять Конституцию главным образом, из-за фундаментального раскола по вопросам религии и государства; во-вторых, взяло на вооружение систему пропорционального представительства. Отметим, что лишь у трех государств в мире отсутствуют конституции: это Израиль, Великобритания и Новая Зеландия. У Великобритании нет писаной конституции (кроме Великой хартии вольностей 1215 г.); Новая Зеландия унаследовала у нее эту традицию. Интересно, что конституция Ирака переняла пропорциональное представительство, что углубило этнорелигиозный раскол. Система "один человек из одного округа", она же "победитель получает все”, она же мажоритарная - обычная в США и Великобритании - имеет свойство в определенной степени “завышать” количество голосов, доставшееся победившей партии, а значит и количество мест, которые она получит в парламенте.

\section{ФОРМАЛЬНАЯ ПОЛИТИЧЕСКАЯ ТЕОРИЯ}

Формальная политическая теория - это ряд утверждений, логически выводимых из совокупности предположений о политике. Политическая теория электоральной демократии была впервые сформулирована Энтони Даунсом (1957). Эта теория соотносит статистическое распределение идео- 
логических и политических позиций электората по ряду критериев с политическими партиями, которые должны получить больше голосов. Другими словами, политические партии формируют свои позиции в соответствии с ожидаемым количеством голосов. Даунс предложил экономическую теорию демократии, которая стала крайне важной для ученых, веривших, что политология должна быть способна создавать теории, опираясь на которые могут быть получены эмпирические утверждения относительно политических феноменов (после того как сами эти теории будут протестированы, как описано выше). Мысль Даунса, проникающая в суть пространственной экономики, проиллюстрирована примером автозаправочных станций, расположенных, как он объясняет, близко друг к другу из-за того, что распределение в пространстве потребителей бензина соответствует статистически нормальной кривой. Вместо того, чтобы открывать бензоколонку, на многие мили отстоящую от другой, можно построить ее неподалеку - со значительной вероятностью привлечь гораздо больше покупателей на обе. Даунс применил эту идею к динамике электоральной демократии. Предположим, что есть две крупнейшие партии - правая и левая. Предположим также, что избирателей экстремистских взглядов меныше, чем избирателей, придерживающихся умеренных взглядов. Чтобы получить больше голосов, кандидаты будут стараться проявлять умеренность в своих высказываниях, идет ли речь о войне или мире, хлебе или масле, чести или унижении. В результате, две главные партии станут похожими друг на друга. Был предпринят ряд попыток подтвердить или опровергнуть эмпирически даунсианскую теорию соревнования партий. Используя шаблоны статистического распределения электората в многомерном пространстве, данная теория показывает, что при представительной демократии избиратели являются независимыми, в то время как кандидаты или политические партии - зависимыми. Этот анализ является одним из примеров того, как формальная политическая теория применялась для объяснения эмпирических феноменов.

Политика осуществляется, как правило, внутри организаций и между ними. Один из ключевых вопросов политики - как люди реагируют на упадок в жизни организации. Альберт Хиршман (1970) сформулировал модель “выхода, голоса и верности". Чаще всего выбор можно увидеть на рынке: это решение приобрести товар или отказаться от него. В жизни организации, если человек обладает "верностью”, то он останется в ее рядах, несмотря на сокращение платы. Опция “выхода" означает, что член организации незамедлительно покидает ее. Существует и третья, более широко распространенная и “политическая": предложить остальным объединить усилия для улучшения жизни организации. Но когда человек начинает думать о глобальных последствиях каждой из этих опций, все становится гораздо более сложным. Представьте себе предрасположенную к опции “выхода" страну, доход в которой существенно не поднимался уже давно, например, Филиппины. Существенную часть своего дохода филиппинцы получают посредством выезда на заработки в США и страны Персидского залива, после чего они возвращаются домой, привозя с собой значительную часть заработанного. Можно предположить, что следствием массовых миграций становится недостаток движущей силы внутреннего развития. В то же время, в предрасположенной к “верности” стра- 
₹ не, например в Японии, не выезжать из страны - обычный ответ на упадок жизни организации, поэтому уровень миграции низок. В низшей точке, когда условия становятся невыносимыми и преданность уже не способна привлечь внимание или вызвать восхищение, “верность” может принять характер “голоса". Это - формальная политическая теория, но с тем же успехом данный вопрос мог бы относиться и к эмпирической политической теории. Теория “выхода, голоса и верности” затрагивает комплексные примеры из жизни организаций, а также различные виды человеческого поведения в попытке ее улучшить. Другими словами, опция “выхода” основывается на конфликте, опция “голоса" - на координации, а опция “верности” - на преданности.

Существуют еще два главных жанра (отличные как от классической философии, так и от эмпирической и формальной политической теории), которые иногда связывают с политической теорией: эпистемология и методология. Эпистемология относится к изучению того, каким образом люди рассматривают в качестве знаний то, что они видят и слышат. Рене Декарт, французский философ (наибольшую известность ему принес трактат "Рассуждения о методе”), фактически изложил современный позитивистский метод. Это ряд советов и инструкций, которые могут оказаться полезными для более четкого осознания наблюдаемого. Методология относится к изучению различных инструментов, посредством которых реальность можно наблюдать и эффективно анализировать.

\section{ШКОЛЫ ПОЛИТИЧЕСКОЙ ТЕОРИИ}

Школы политической теории отчасти смешиваются, так как эмпирическая политическая теория выросла (по крайней мере - изначально) из других дисциплин, таких как психология, психиатрия, социология, экономика и антропология. Один из непосредственных источников эмпирической политической теории можно обнаружить в глубоких трансформациях и новых потребностях, возникших после Второй мировой войны. Применение методологий и концепций из этих дисциплин в политологии впервые осуществили Самуэль Стауффер и Гарольд Лассуэлл. Для ученых, занимавшихся эмпирической политической теорией, единственными методами были исторические и институциональные описания. С появлением новых методологий и концепций кругозор теории резко расширился. Наблюдение, измерение и оценка стали традиционными инструментами политологии, что позволило школам эмпирической политической теории активно развиваться. До Второй мировой войны политология занималась в основном конституциями и институтами, с одной стороны, и политической философией - с другой. Война также стала катализатором для развития эмпирической политической теории, так как правительства были заинтересованы в измерении и оценке боевого духа своих войск, эффективности пропаганды и военных действий. Стауффер с коллегами провели исследование на тему боевого духа, которое внесло значительный вклад в развитие исследований, основанных на проведении опросов; аналогичный анализ пропаганды провели Гарольд Лассуэлл и Итиэль де Сола Пул. Исследование эффекта от бомбардировок Роберта Макнамары и его коллег внесло значительный вклад в развитие стратегического анализа 
издержек и выгод. Другим примером является изучение военной оккупации, проведенное Рут Бенедикт, путем психокультурного анализа японского народа. Потребовалось более двух десятилетий после окончания Второй мировой войны, чтобы эмпирическая политическая теория заняла должное место в политической науке.

Что касается нормативной политической теории, ее школы, как правило, связаны с великими философами, такими как Аристотель, Никколо Макиавелли, Джон Локк, Карл Маркс, Мишель Фуко и Юрген Хабермас. Но расширение взаимодействия с другими дисциплинами, как и с соответственными методологиями и концепциями, также способствовало развитию школ нормативной политической теории.

\section{ЧЕТЫРЕ ШКОЛЫ НОРМАТИВНОЙ ТЕОРИИ}

Согласно Расселу Хардину, выделяются четыре ключевых основания нормативной политической теории: конфликт, общие ценности, обмен и координирование.

\section{КОНФЛИКТ}

Одной из ведущих фигур нормативной политической теории, центром внимания которой выступает конфликт интересов, является Карл Шмитт (19221985), определяющий политику как отношения дружбы-вражды внутри и между нациями. Его теорию обычно относят к ультраконсервативным, а порой к фашистским. Объяснительный потенциал теории Шмитта в значительной степени связан с конфликтными ситуациями, такими как война; в мирном контексте она мало применима. Клаузевиц определяет войну как не более чем продолжение политики другими методами, как и маршал Советского Союза Борис Шапошников. Поскольку и Клаузевиц, и Шапошников были боевыми офицерами, их теории зачастую воспринимаются как руководство к действию; однако простота и ясность их работ привлекательна для исследователей, изучающих войну и конфликт. Труд марксистского толка, фокусирующий внимание на классовом конфликте, - книга "Социальное происхождение диктатуры и демократии” Баррингтона Мура (1966-1993), - может восприниматься как нормативная политическая теория, в центре которой лежит классовый конфликт. По автору, основополагающий характер в нем носит эволюция сельского хозяйства, с которой были связаны подъем демократии, фашизма и коммунизма в XX в. Так, коммерциализация сельского хозяйства способствовала развитию и установлению демократии в Англии и Франции; пассивность землевладельческого класса привела к стагнации сельского хозяйства в Германии, Японии и Италии и приходу к власти фашистских сил, а интенсивная эксплуатация сельского хозяйства способствовала приходу коммунизма в России и Китае.

\section{ОБЩИЕ ЦЕННОСТИ}

Нормативная политическая теория, в центре внимания которой были общие ценности, доминировала в XX в., особенно после “холодной войны”. Господство общих ценностей и развитие соответствующей теории было в немалой степени связано с подъемом и распространением либеральной демократии, 
ะ которая основывается на агрегировании предпочтений граждан, как его описывал Даунс (1957). Фактически, для функционирования либеральной демократии необходим режим, в котором ключевую роль играют общие ценности. Важно отметить, что либерализм не требует знания или разделения ценностей других индивидуумов. “Экономическая теория демократии” Даунса это формальная политическая теория с нормативными предписаниями. Ценности часто иллюстрируются на примере идеологии “левые-правые”. При двухпартийной системе как левая, так и правая партии склонны двигаться к центру. “Центристские” граждане разделяют общие ценности, тогда как маргинальные ценности имеют мало единомышленников. Чтобы получить голоса, партии выбирают своей целью центральную точку, в которой сосредоточено значительное число избирателей, и соответственно корректируют свои идеологические и политические позиции. Объяснительный потенциал такой теории высок, особенно когда подъем глобализации ослабляет средние и крупные национальные институты и возрастает значимость отдельного гражданина.

\section{ОБМЕН}

Нормативная политическая теория, основанная на обмене, представлена Адамом Смитом. Широко известно, что из двух главных работ Смита “Теория нравственных чувств" и “Исследование о природе и причинах богатства народов" - первая объясняет источники способности человека выносить моральные суждения. Его ключевой концепцией является сочувствие, 132 посредством которого наблюдение за окружающими заставляет людей понимать их поведение, а также то, насколько морально их собственное поведение. Без сочувствия в межличностных связях обмен теряет свою опору. Даже когда обмен осуществляется на национальном и глобальном рынках, он нормально функционирует, только если основан на сочувствии в социальных связях. Сочувствие иногда обозначается как социальный капитал (в том числе в работах Джеймса Коулмана и Роберта Патнэма). В то же время очевидно, что одних лишь инструментов и механизмов обмена недостаточно. Базирующаяся на нем нормативная политическая теория оптимальна в тех рамках, в которых обмен позволяет разрешать различные конфликты.

\section{КООРДИНИРОВАНИЕ}

Как ни странно, но понятие координирование не играло существенной роли в развитии нормативной политической теории. Естественно, нормативная политическая теория, основанная на конфликтах, превалирует, учитывая, что к любой политике относятся как к имеющей дело с ситуациями конфликта интересов и связями типа “дружба-вражда”. Естественно, что нормативная политическая теория, основанная на обмене, также превалирует, так как разрешение конфликтов часто может быть достигнуто путем извлечения выгод из обмена уступками как в мелких, так и в крупных вопросах. Хардин (2009) указывает, что развитием нормативной политической теории, основанной на координировании, занимались недостаточно - возможно, из-за недостаточного понимания координирования как схемы и инструмента политики в системе координат нормативной политической теории. Даже аргумент 
Гоббса в пользу абсолютистского правления, осуществляемого суверенным монархом, может быть рассмотрен как нормативная политическая теория, описанная в понятиях координирования, если гоббсовскую теорию переформулировать внутри многоуровневой и многоэтапной системы координат. В такой системе координат мощной концепцией является стратегия. Определение того, каким образом следует координировать свое поведение, когда вы руководствуетесь стратегией $A$, а ваш соперник - стратегией $B$, задача сложносоставная. Осуществление двухпартийного координирования, основанного на многоуровневых и многоэтапных стратегиях, делает нормативную политическую теорию более сложной, многоплановой. В то же время, это направление теоретизирования разрабатывалось с середины XX в. в других дисциплинах, таких как военное дело, бизнес-менеджмент и различные направления проектирования, часто в форме теории игр. Нормативная политическая теория с координированием в качестве ключевого концепта обязана развиваться, поскольку политика в очень существенной степени полагается на координирование.

\section{ШЕСТЬ ШКОЛ ЭМПИРИЧЕСКОЙ ПОЛИТИЧЕСКОЙ ТЕОРИИ}

Как уже отмечалось ранее, школы эмпирической политической теории непросто классифицировать. Ключевыми ее вехами являются бихевиористская революция (1950-1960-е годы) и постбихевиористская революция (19701980-е годы), за которыми последовало движение перестройки в Американской ассоциации политической науки (1990-2000-е годы). После бихевиористской революции приобрели известность теория систем и бихевиоризм; после постбихевиористской революции были предприняты новые попытки, выходящие за пределы достигнутого ранее. Постбихевиористская революция и движение перестройки попытались сделать политологию более интерпретативной, рефлективной, чувствительной к контексту и предрасположенности к пути развития, с одной стороны, а с другой - в большей степени сфокусированной на институтах, а не индивидуумах; на строгих, тщательных утилитаристских вычислениях, а не на мотивациях, выявленных из культуры; на нейрофизиологическом движении, а не внешнем поведении человека; и на глобальном мировоззрении, в противовес взгляду на нацию как на органичное целое.

\section{СИСТЕМНАЯ ТЕОРИЯ}

Неудовлетворенный состоянием политологии в 1940-х годах (в то время она очень отличалась от той, какой мы знаем ее сегодня), в течение 1960-х годов Истон пытался сделать политологию научной дисциплиной, теории которой были бы получаемы из эмпирического тестирования теоретически сформулированных гипотез на базе систематически генерируемых данных. Таким путем Истон намеревался создать “общую теорию” политики в рамках системной теории. Знаменитое истоновское определение политики как “авторитетного распределения ценностей в обществе” было рождено из этого мышления в рамках теории систем. Оно подействовало освежающе на тех политологов, кто был разочарован политологией того периода, с ее концентрацией на конституциях и институтах, с одной стороны, и идеях и идео- 
ヶ логиях - с другой. Истон, вместе с Джеком Деннисом, пошел по пути изучения политической системы с точки зрения политической социализации детей, посредством которой дети получали знания о политике от родителей, сверстников, учителей и проповедников. Нормы, ценности и правила - это компоненты, передающиеся в политической системе от одного поколения к другому. Самопровозглашенные политологи, на которых повлияла теория систем, возможно ощущали, что политическая система является обширным и сложным набором взаимодействий акторов под широкой матрицей правил и норм, и что теоретизировать на эту тему на уровне систем, основываясь на эмпирически полученных данных - определенно отчаянная задача. Бихевиористская революция бушевала в США одновременно с принятием мышления в рамках теории систем. Вслед за этим на фоне сложной международной ситуации конца 1960-х - начала 1970-х годов произошло некоторое отрезвление в отношении как теории систем, так и бихевиоризма в политологии; стали остро ощущаться ограничения теории систем. Сам Истон позднее признавался, что его системный анализ и бихевиоризм имели четкие границы.

\section{БИХЕВИОРИЗМ}

Призывы к бихевиоризму приветствовались как имеющие революционное значение теми энтузиастами, которые провозгласили, что она преобразит политологию из устаревшей, поросшей мхом дисциплины в одну из современнейших, общепризнанных наук, в которой основное внимание будет уде-

134 ляться скорее действию, чем намерению и мотивации, и скорее анализу, чем интерпретации. Несмотря на то, что энтузиазм в отношении бихевиоризма продлился недолго, дух и стиль бихевиоризма закрепились в пользующихся всеобщим уважением журналах.

Возвращаясь к объяснительному потенциалу эмпирической политической теории, мы можем обсудить теорию демократического мира Брюса Рассетта (1993). Подвергшаяся тестированию гипотеза является одним из тезисов, впервые выдвинутых Кантом: республиканский режим (в отличие от монархического) менее предрасположен к развязыванию войны с другой республикой, чем с нереспубликанским режимом. Выражаясь современным языком, данная гипотеза утверждает, что демократии редко воюют друг с другом. Рассетт воспользовался совокупностью данных временного ряда, составленных по всем суверенным государствам, разбитым на пары, за каждый год с 1815 до 1989 гг.

\section{ТЕОРИЯ РАЦИОНАЛЬНОГО ВЫБОРА}

Теория рационального выбора родилась из формальной политической теории. В то же время она, как правило, привязана к тестированию утверждений, которые логически получаются из определенного ряда предположений и аксиом. Отчасти она была обязана своим подъемом устойчивому влиянию экономики на политологию. Также, среди субдисциплин политологии, политэкономия (которая, благодаря воспитанным на экономике ученым, таким как Энтони Даунс, Мансур Олсон и Геральд Крамер, приобрела немалую влиятельность) широко изучалась в 1970-х и 1980-х годах. Причиной 
этого отчасти являлась реакция, направленная против того вида бихевиоризма, который был подвергнут критике как слепой и ничем не оправданный эмпиризм. Книга “Экономические истоки диктатуры и демократии” (2005) Дарона Асемоглу и Джеймса Робинсона может послужить тому примером. Она начинается с описания социальных групп, которые предпочитают разные политические институты с различными способами распределения власти и ресурсов. Группы, владеющие богатыми ресурсами, стремятся монополизировать власть; остальные хотят демократии. Со временем демократия начинает побеждать, потому что этого желает большинство. Отметим, что в Таиланде старые элиты не уступили, когда массы захватили власть, и вернули ее обратно, прибегнув к военному государственному перевороту. Но их логика имеет внятный и общий характер, в отличие от политологических докладов о подобного рода борьбе между демократией и диктатурой, которые являются, в общем-то, описательными.

\section{ИНСТИТУЦИОНАЛИЗМ}

Для обособления от институционализма прошлого, сегодняшний институционализм называют неоинституционализмом. Его ключевыми чертами являются: (1) сильный эмпиризм, использующий детальные институциональные механизмы, и (2) подчеркнутый компаративизм институтов, использующийся для усиления аргументации. Контраст, возникающий вследствие этого, направлен на то, чтобы сделать общую направленность и результат институционализма более ясными. Если Асемоглу и Робинсон являются типичными исследователями - представителями теории рационального выбора, то Джон Фереджон - типичный институционалист. Асемоглу и Робинсон формулировали и проводили тестирования в обобщенной манере; Фереджон формулирует и тестирует в более сопоставительной манере, используя в полной мере компаративные упражнения в формулировании и тестировании гипотез. Эти черты ярко выражены в его работе по федерализму, войне и государственному строительству. Ограничение институционализма может быть определено как зависимость от сферы и угла рассмотрения компаративных институциональных мониторингов и расследований в том случае, если он изучает электоральные последствия электоральных правил, таких как пропорциональная и мажоритарная репрезентативность или последствия социальной политики системы налогообложения.

\section{НЕЙРОАНАЛИЗ}

В течение революционного периода бихевиоризма "Основы политического анализа" и "Системный анализ политической жизни” Истона могли быть названы библией бихевиоризма. Другая работа, которую можно считать влиятельной, это “Нервы управления” Карла Дойча (1963). В ней выделяется важность нервов в теле политики, - они обеспечивают поступление информации и “обратную связь”. Этот труд в каком-то смысле может считаться предтечей всей нейробиологической школы политики, хотя в его системе координат и не нашлось места углубленным исследованиям нейронов и других нейрофизических компонентов и функций. Поскольку интересы Дойча смещались от социальной коммуникации и национализма в отдельно взятой 
₹ стране в сторону региональной интеграции по обе стороны Атлантики, его часто относят к бихевиористам. Устойчивое развитие нейрофизиологии с 1990-х годов, возможно, сделало Дойча истинным предтечей нейроанализа. Если Тип О’Нил прав, говоря: “Вся политика локальна”, - то нейрофизиолог прав, когда он утверждает: "Вся политика пронизана нервными окончаниями”. Нейроанализ резко контрастирует с бихевиористским анализом в том отношении, что первый уделяет основное внимание намерению и мотивации (как они раскрываются путем изменений в нейронах мозга), а второй - конкретному, визуально воспринимаемому действию. При этом первый не пытается установить реальные намерения и мотивации. Научный прогресс например, визуализация магнитного резонанса и другие технические достижения - сделал возможными интерпретацию и понимание человеческих намерений и мотивов. Так, при наблюдении за подозреваемыми в совершении преступления необходимы как сбор материальных улик, так и понимание их мотивов. Нейроаналитические данные все чаще используются для исследования политики. "Зеркала в мозге: как наш разум разделяет чужие действия, эмоции и опыт” Джакомо Риззолатти и Коррадо Синигальи (2008) раскрывает то, какую пользу политология может получить от нейроанализа. Хотя нейроанализ и не ограничивается политологией, его применение должно расширяться и дальше, ведь сложность политики лежит в постижимости движения нейронов.

\section{ГЛОБАЛИЗМ}

136 Политология на заре XXI в. одновременно продвигается в двух прямо противоположных направлениях: одно из них - нейронное, другое - глобалистское. Прогресс в науке и технологии позволил людям устанавливать связь друг с другом на далеких расстояниях и с высокой скоростью, чтобы ухватить “макросуть” и “микросуть” политики. Волне глобализации придали энергию технологические достижения XX в. Одним из них стала электронная революция в коммуникациях, которая позволила движению денег “сойти с ума", говоря словами Сьюзен Стрэндж. Теперь они (как и товары, образование, медицина, мигранты, вирусы, преступления, наркотики, оружие и информация) перемещаются невероятно быстро. Политика не стала исключением для этой волны глобализации, которой невозможно сопротивляться или “дать обратный ход”. Дэвид Хельд (1995) является типичным глобалистом. Его “Демократия и глобальный порядок” выстраивает нормативный базис космополитичной демократии, основанной на различных теориях демократии. Тот предел, до которого нормативная политическая теория по-настоящему универсальна и глобальна одновременно, обсуждался до недавних пор, так как значительная часть нормативной политической теории родом из современной Европы, где как государственное строительство, так и формирование политической теории осуществлялись, по большей части, в государственном масштабе.

\section{ДИАЛОГ МЕЖДУ НОРМАТИВНОЙ И ЭМПИРИЧЕСКОЙ ТЕОРИЯМИ}

Таким образом, данная статья подвела итог под тремя видами политической теории: классической, эмпирической и формальной. В ней также было 
показано, что они тесно связаны друг с другом. В этом разделе будут приведены некоторые примеры с целью показать, что нормативная и эмпирическая политические теории могут плодотворно взаимодействовать такими способами, которые помогут им высказываться более резко и точно, а также выявлять “слепые пятна", таким образом обогащая друг друга. Приводимые для иллюстрации данного заявления примеры включают в себя типологию воинственных демократий и восходящих режимов. И те, и другие берут свои утверждения из классических политических теорий, таких как теории Канта, Макиавелли, Аристотеля и Шарля де Монтескье, и проводят их эмпирическое тестирование, чтобы увидеть, насколько нуждаются в пересмотре как классическая, так и эмпирическая теории.

Нормативная политическая теория подразумевает преодоление конкретного времени и места, в которых она зародилась из спора о том, каким путем должна быть достигнута справедливость. Одним словом, в этом ee raison d'être. В то же время общепризнано, что в нормативной политической теории обычно доминируют темы, связанные с конфликтами, общими ценностями и обменом. Особенно много исследований, связанных с общими ценностями. Отчасти это объясняется тем, что во второй половине XX в. политологические публикации и их аудитория в основном состояли из американских ученых, демонстрировавших устойчивую приверженность к либерализму. Эмпирическая политическая теория также подразумевает преодоление рамок конкретной временной и пространственной ситуации, чтобы быть верной в любых условиях. В то же время, общепризнано и то, что значительная часть эмпирической политической теории была сфокусирована на вторую половину XX в., а также на США и ЕС. В совокупности эти два факта являют серьезную проблему: эмпирическая политическая теория весьма склонна представлять Запад как фонтанирующий источник универсальной истины и справедливости.

Стоит отметить, что Кант, всю жизнь проживший в Кенигсберге и бывший свидетелем череды изменений в европейских странах, уловив волну будущего, описал ее в наиболее сжатом виде. Хотя демократии обычно живут в мире друг с другом, они склонны воевать с недемократическими режимами, которые, как они ожидают, несут угрозу их существованию. Радикальные правые кантианцы появились в 2000-х годах после террористических атак 11 сентября 2001 г. и войн в Афганистане и Ираке. Они утверждали, что если бы Кант был жив и наблюдал за этими событиями, то он бы поддержал войну в Ираке, чтобы удержать иракское государство, предположительно обладавшее оружием массового уничтожения, от его использования. Они утверждали также, что демократии не могут быть пассивными и просто сидеть сложа руки, в то время как невинных граждан убивают, а демократиям бросают вызов угрозой применения силы. Вместо этого демократии должны сражаться против антидемократических сил. Разительный контраст с доводами в пользу интервенции демократических государств, приводимыми кантианцами правого толка, составляют утверждения кантианцев левого толка, выступающих за демократию, которая отвергает внешние вмешательства в свои внутренние демократические процессы (суверенную демократию, по Суркову). Это относится к инцидентам, которые имели место в связи с демократизацией и сепара- 
тистскими движениями в тех обществах, которые были объединены в рамках бывшего Советского Союза (например, в Чечне, Грузии, Украине и Киргизии).

В конце XVIII в. Европа стала свидетельницей Французской революции и наполеоновских войн. Кант верил, что пришествие республиканского режима, свободной торговли и многосторонних договоров, а также международных организаций, возвестит о начале вечного мира. Очевидно, что идеи Канта были существенно обусловлены временем и пространством. На рассвете XXI в. мы становимся очевидцами террористического налета 11 сентября и войн в Афганистане и Ираке, ведущих к спорам между правыми и левыми последователями Канта о том, являются ли “гуманитарные интервенции" оправданными в целях привнесения демократического режима извне, как об этом заявляют кантианцы правого толка, или нет, как полагают кантианцы левого толка. Таким образом, можно сделать вывод, что нормативная политическая теория привязана к контексту.

По мнению Джона Фереджона и Франца Розенблюта (2008), в соответствии с другой линией аргументации у кантианских республик есть два вида механизмов сдержек и противовесов. Горизонтальный контроль - это механизмы, работающие на более высоком уровне законодательной и исполнительной власти. Представители законодательной власти и представители исполнительной власти - это разные люди, которые отделены друг от друга. Ни одна сторона не может диктовать свою волю другой, и, таким образом, сдерживающие механизмы режима работают лучше, чем могло бы быть в противном слу-

138 чае. Вертикальный контроль - это механизмы, действующие между различными уровнями элиты и граждан. Республиканские демократии Канта проводят различие между элитами, принимающими решения, и гражданами, формирующими эти решения; но только при том условии, что они взаимодействуют друг с другом. Иными словами, элиты учитывают предпочтения граждан относительно принимаемых решений, а граждане выражают свои предпочтения вербально, четко и понятно для элит, помогая им формулировать решения. Фереджон и Розенблют утверждают, что Канта следует отличать от Макиавелли в том отношении, что республиканские демократии, вооруженные механизмами сдержек и противовесов по Канту, по касательной ограничивают теорию демократической мобилизации Макиавелли и, соответственно, - его теорию воинственной демократии. Утверждения Макиавелли основываются на сравнении республиканского Рима с монархической Флоренцией. У республиканского Рима были солдаты, чья мотивация к войне и способность ее вести были высокими, так как это был политически инклюзивный режим. Монархическая Флоренция была наводнена купцами, мотивация которых к войне, как и способность ее вести, была невысокой. Фереджон и Розенблют используют Макиавелли для того, чтобы осмыслить, что же такое “воинственная демократия", учитывая опыт конца XX - начала XXI вв. Таким образом, согласно их теории, “миролюбивые” и “воинственные” демократии это не есть что-то различное.

В 1835 г., сосредоточив свое внимание на вооруженных силах демократий, Алексис де Токвиль выявил изначальную опасность военных действий, которые могли бросить тень на репутацию демократий. По наблюдению 
Токвиля, армия в Америке защищала захватчиков, которые разоряли землю, изначально заселенную местными жителями, нарушали заключенные с туземцами перемирия и мирные договоры. Армия обрела широкую поддержку со стороны американцев, которые продвигались к западу от тех земель на Атлантическом побережье, на которых они первоначально обосновались, так, словно это было “велением самой судьбы”, еще до того, как это выражение вошло в повседневный лексикон. Токвиль испытывал тревогу по отношению к военным и их поведению, узаконенному демократиями, идеи которых он рьяно поддерживал и очевидно ими восхищался. Другими словами, демократический мир и склонность к войне являются двумя сторонами одной медали.

Американские авторы, такие как Макс Бут и Роберт Каган, приходят к тем же выводам: американцы были готовы использовать силу при улаживании конфликта интересов за границей еще до того, как обрели независимость от Англии. Обоих авторов в США называют неоконсерваторами; в России их называют "большевиками XXI столетия". У американских неоконсерваторов и российских большевиков, направляемых В.И.Лениным в течение предыдущего века, есть две общих черты: они идеалисты, неизменно сочувствующие тем идеалам, которых стремятся достичь, и они же - реалисты, легитимизирующие использование силы в том случае, если их casus belli считается достаточно справедливым в свете их же собственных идеалов, таких как демократия и права человека. Возможно, Токвилль был прав в своих мрачных предчувствиях, поскольку он пережил демократический империализм в Европе в форме революционной войны, которую вел Наполеон Бонапарт.

Приверженцы классической политической теории часто поднимают вопрос типологии режимов. Аристотель в своей "Никомаховой этике" утверждает, что этика - это основа политики. Таким образом, в зависимости от этики, превалирующей в обществе, можно выделить три типа режимов: монархия, аристократия и полития. Монархия формируется тем типом этики, который превалирует в отношениях между отцом и сыном; аристократия - типом этики, превалирующим в отношениях между мужем и женой; а полития - типом этики, господствующим в отношениях между старшим и младшим братьями. Теория Аристотеля является монадической в том смысле, что с момента идентификации однажды превалирующей этики тип режима определяется автоматически. Трактат “О духе законов” Монтескье (1748) также является монадическим. Три типа режимов - республика, монархия и автократия - определяются движущим духом режима. Движущая сила республики - добродетель; аристократии - честь; автократии - страх. Очевидно, что связь между гражданами и государством является монадической и что с того момента, как однажды тип режима определен, превалирующая этика граждан определяется соответственно. В конце XIX - начале XX вв. Вебер говорил об определении типов режимов через средства управления (харизма, сила и законная рациональность). Опять же и здесь прослеживается монадическая тенденция. С того момента, как однажды средства определены, определены и типы режимов - и наоборот. Состояние дел не сильно изменилось ни к концу XX в., ни к началу XXI в. К примеру, Стейн Роккан в 1960-х годах описал формирование демократических государств в евро- 
๘ пейской истории. В то же время, Роккан говорит только о типах режимов, а не о гражданах. Можно удивиться, почему так мало интереса было проявлено к гражданам и их связи с государством, когда опросы на данную тему проводились по всему миру, включая многие авторитарные государства. До недавних пор можно было объяснить недостаточность обсуждения граждан в теоретических изысканиях на тему государства тем, что главные теории касаются скорее институтов, чем социальных акторов.

Согласно "Никомаховой этике" Аристотеля, этика, которую разделяет и которой придерживается определенная группа людей, является определяющей для типа режима. Внутри политии Аристотель выделял три подтипа: автократия, олигархия и демократия. Каким образом определяются эти три подтипа политии? Некоторые ученые полагают, что с дисциплинарной точки зрения они не настолько четко выявляются путем простого определения соответствующей этики, как это возможно в случае с монархией и аристократией, где достаточно определить то, что называется социетальным режимом, превалирующим “в низах общества”. В данном случае этика понимается в более широком смысле - как господствующая политическая культура, ключевые компоненты которой определяются как идентичность, доверие и удовлетворенность. Эти немногие типы социетальных режимов не сформулированы на абстрактном уровне, который мог бы быть удобен для некоторых специалистов по политической теории. Однако важно указать на необходимость начать разговор на эту тему. Как специалисты по классической теории, так и последователи эмпирической теории могут начать с того, что им

140 представляется наиболее комфортным. Важно, чтобы они продвигались в новом направлении, которое может привести их к диалогу “лицом к лицу” вместо “рытья окопов” по обе стороны “линии Мажино” между двумя школами теории.

По мере сбора данных, полученных в течение продолжительного времени в результате опросов и прочих операций, специалисты по эмпирической политической теории должны разрешить задачу всеохватывающего определения типа режима. То же относится и к специалистам по нормативной политической теории. Ни те, ни другие не должны дискутировать о типах режимов, не изучая при этом "нижний уровень" - а именно, нас, граждан. Проблемы с теорией на этом не заканчиваются: даже если говорить в самом общем плане, в применении термина “демократия” остается еще много неясного.

Перевод Е.С.Сычевой 